\title{
Mulberry leaves treated with bordeaux mixture protect silkworm caterpillars against fungal and viral diseases
}

\section{Folhas de amoreira tratadas com calda bordalesa protegem lagartas de bicho-da-seda contra doenças fúngicas e virais}

\author{
Juliana Fernandes ${ }^{1}$; Rose Meire Costa Brancalhãoº ; Daniel Nicodemo ${ }^{3 *}$; \\ Lucinéia de Fátima Chasko Ribeiro ${ }^{4}$; Marilucia Santorum ${ }^{5}$
}

\begin{abstract}
The bordeaux mixture is used as a natural agricultural fungicide, and its application in sericulture can benefit the production of silkworm cocoons, Bombyx mori (Lepidoptera: Bombycidae). The aim of this study was to verify whether the bordeaux mixture exerts a protective effect in $B$. mori against fungal and viral diseases. This experiment was performed during two seasons, autumn and spring, in which 7,500 caterpillars were used at the beginning of the third instar and divided into five groups, with three repetitions of 500 individuals each. In the three groups, the caterpillars were fed leaves of Mulberry (Morus spp.) that were enriched with an aqueous bordeaux mixture solution at concentrations of 5 , 10 and $20 \%$. One group was fed exclusively mulberry leaves (control), and another was fed leaves that were moistened with water. Fungal contamination was evaluated in the integumentary surface of the insect and the mulberry leaves in the bed of creation by checking the number of colony-forming units (CFU). In the analysis of viral contamination, 20 caterpillars from each group at the beginning of the fifth instar were inoculated with $10 \mu \mathrm{l}$ of a suspension of Bombyx mori nucleopolyhedrovirus (BmNPV). Daily, from the second to the ninth day after inoculation (dai), two caterpillars of each group were anesthetized and formalin-fixed $7 \%$ for microscopic processing and viral cytopathology analysis. A completely randomized design was used, and the CFU were compared by Tukey test with $5 \%$ significance. The results showed a decrease of $55.1 \%$ in CFU present on the mulberry leaves in the fall, when the $5 \%$ bordeaux mixture solution was used. There was no significant difference between the groups based on the bordeaux mixture in this period. During the same period, reductions of CFU of $28.5,74.9$ and $74.4 \%$ were verified in the integument of $B$. mori when bordeaux mixture solutions of 5,10 and $20 \%$ were used, respectively, compared with the data that were obtained in the control group. In the spring, no difference was observed between the groups that received bordeaux mixture solution and the control. In the case of BmNPV, the $10 \%$ bordeaux mixture solution promoted greater resistance to viral infection, possibly favoring the activation of defense mechanisms of insects. Therefore, we recommend the use of a $10 \%$ bordeaux mixture solution in mulberry leaves to control fungal and viral diseases in silkworm rearing.
\end{abstract}

Key words: Lepidoptera, baculovirus, Bombyx mori, sericulture

1 Discente do Curso de Graduação em Zootecnia, Campus de Dracena, Universidade Estadual Paulista "Júlio de Mesquita Filho", UNESP, Dracena, SP, Brasil. E-mail: juhfernandes1@hotmail.com

2 Prof ${ }^{a}$ Associado, Centro de Ciências Biológicas e da Saúde, Campus de Cascavel, Universidade Estadual do Oeste do Paraná, UNIOESTE, Cascavel, PR, Brasil. E-mail: rosecb@gmail.com

3 Prof. Assistente, Campus de Dracena, UNESP, Dracena, SP, Brasil. E-mail: nicodemo@dracena.unesp.br

4 Prof ${ }^{a}$ Adjunto, Centro de Ciências Médicas e Farmacêuticas, Campus de Cascavel, UNIOESTE, Cascavel, PR, Brasil. E-mail: lucineia.cr@gmail.com

5 M.e em Biociências e Sáude, UNIOESTE, Campus de Cascavel e Doutoranda em Biotecnologia do Campus de Botucatu, UNESP, Botucatu, SP, Brasil. E-mail: mari_santorum@hotmail.com

* Author for correspondence 


\section{Resumo}

A calda bordalesa é um produto usado como fungicida agrícola natural e sua aplicação em sericicultura pode beneficiar a produção de casulos do bicho-da-seda, Bombyx mori (Lepidoptera: Bombycidae). O objetivo deste estudo foi verificar se a calda bordalesa exerce efeito protetor em B. mori contra doenças fúngicas e virais. $\mathrm{O}$ experimento foi realizado em dois períodos sazonais, outono e primavera, sendo utilizadas 7.500 lagartas no início do terceiro instar, divididas em cinco grupos, com três repetições de 500 indivíduos cada. Em três grupos as lagartas foram alimentadas com folhas de amoreira (Morus spp.) enriquecidas com solução aquosa de calda bordalesa nas concentrações de 5,10 e $20 \%$. Um grupo foi alimentado exclusivamente com folhas de amoreira (controle) e outro com folhas umedecidas apenas com água. A contaminação fúngica foi avaliada na superfície tegumentar do inseto e nas folhas de amoreira presentes na cama de criação, através da verificação do número de unidades formadoras de colônias (UFC). Já na análise da contaminação viral, 20 lagartas de cada grupo, no início do quinto instar, foram inoculadas com $10 \mu \mathrm{l}$ da suspensão de Bombyx mori nucleopolyhedrovirus (BmNPV). Diariamente, do segundo ao nono dia após a inoculação (dpi), duas lagartas de cada grupo foram anestesiados e fixadas em formol 7\%, para o processamento microscópico e análise da citopatologia viral. Foi adotado um delineamento inteiramente casualizado e as médias de UFC foram comparadas por teste de Tukey, com 5\% de significância. Os resultados revelaram uma redução de 55,1\% nas UFC presentes nas folhas de amoreira no outono, quando foi utilizada a solução $5 \%$ de calda bordalesa. Não houve diferença significativa entre os grupos à base de calda bordalesa neste período. Neste mesmo período, foi verificada, no tegumento de B. mori, uma redução da UFC de 28,5, 74,9 e 74,4\%, quando foram usadas soluções de 5,10 e $20 \%$ de calda bordalesa, respectivamente, em relação aos dados obtidos no grupo controle. Na primavera, não foi observada diferença entre os grupos que receberam calda bordalesa e o controle. No caso do BmNPV, contatou-se que a solução de $10 \%$ de calda bordalesa promoveu maior resistência à infecção viral, possivelmente favorecendo a ativação de mecanismos de defesa dos insetos. Sendo assim, recomenda-se a utilização de calda bordalesa à $10 \%$ sobre as folhas de amoreira para o controle de doenças fúngicas e virais na sericicultura.

Palavras-chave: Lepidóptera, baculovírus, Bombyx mori, sericicultura

\section{Introduction}

In sericulture, the quality of silk yarn is directly related to the quality of Bombyx mori (Lepidoptera, Bombycidae) cocoons because these are raw materials. Thus, the challenge is to search for increasing productivity and improve the quality of silk threads (CORRADELO, 1987; NICODEMO et al., 2014).

Among the problems that are associated with sericulture and that directly affect the quality of silk threads are entomopathogens, among which viruses and fungi have a prominent position. In Brazil, there have been several studies of viruses of the Baculoviridae family and Alphabaculovirus, including Bombyx mori Nucleopolyhedrovirus (BmNPV), that have analyzed their mode of action, cytopathology and targets of infection tissues. This pathogen easily spreads in the insect's body, especially via the hemolymph and tracheal system, and can spread in the environment by the shedding of $B$. mori via feces, regurgitation or injuries in the integument of infected larvae (AMARAL; ALVES, 1979; BRANCALHÃO, 2002; BRANCALHÃO; RIBEIRO, 2003).

In the rearing shed, the control of established diseases is difficult and practically uneconomical; thus, the adoption of preventive measures is a precondition to prevent the spread of microorganisms that can decimate creation (OKINO, 1982; FONSECA; FONSECA, 1988; TINOCO et al., 2000; PARRA, 2001). This concern is justified by the characteristics of sericulture, which contributes to the incidence of contamination. Among these features are a high concentration of caterpillars under confinement; a short life cycle, which limits the time to combat the disease; direct contact with employees; relatively higher temperature and humidity; little control over contamination of 
the mulberry branches that are brought from the field; the large production of organic waste and the rusticity of the sheds, which make it difficult to complete disinfection; and the very nature of the activity of clustering large numbers of sheds in a single region.

The limited availability of disinfectants and other products that are not toxic to caterpillars is another factor to consider. Chemical disinfectants that are used in sericulture present restrictions due to the risk of poisoning not only the caterpillars but also farmers, thus greatly limiting the available product options. However, it must be considered that the same product, when used consistently for a long period, can present ineffectiveness in combating certain entomopathogen groups due to the emergence of resistance to one or more active ingredients or by increasing insect susceptibility to infections (SURENDRA; SURENDRA, 1999). It is therefore necessary in activities undergoing constant disinfectant use to periodically rotate the active ingredient; therefore, studies must be conducted in the search for compounds with potential use in controlling entomopathogen (PORTO et al., 2005).

Bordeaux mixture is a traditional agricultural fungicide compound of copper sulfate and hydrated lime in a simple mixture and is effective over a wide range of fungal diseases in crops, such as persimmon, citrus, orchids, strawberries, and tomatoes (DINIZ et al., 2006). The syrup also provides nutrients, such as copper, sulfur, and calcium, which contribute to the nutritional balance of plants (PAULUS et al., 2000; MARTINS et al., 2014). This mixture also acts against bacterial infections and certain pests. Peruch and Bruna (2008) obtained satisfactory results in reducing the incidence of disease in Goethe type vines by applying a dose of $0.4 \%$ bordeaux mixture. Its use in organic agriculture is favored for not exercising considerable toxic effects on man and the environment (SOUTO et al., 2011).

In the case of $B$. mori, studies have been conducted on the incorporation of additives to mulberry leaves, such as ascorbic acid and sterols, aiming to improve nutrition, insect development and silk productivity, including compounds that also act on the immune response against pathogens with important anti-infective roles (GALLO et al., 2002;. KANAFI et al., 2007).

In this sense, considering the need to control pathogens of $B$. mori and the replacement and rotation of chemicals that are used for disinfection in sericulture and that are not toxic to humans and the environment, this study evaluated the use of bordeaux mixture to control diseases caused by fungi and viruses that affect the creation of Bombyx mori.

\section{Material and Methods}

Silkworms (Bombyx mori) in the early third instar were divided into five groups, with 1,500 caterpillars in each group. The caterpillars were fed mulberry leaves (Morus spp.) in four daily treatments (7:30 a.m., 11 a.m., 3:30 p.m. and 7:30 p.m.) in equal amounts among the groups, considering the potential food consumption by the caterpillars (POLYCARPO et al., 2012). Group 1 (G1), the control, was fed only mulberry leaves; Group 2 (G2) was fed mulberry leaves that were moistened with water; and groups 3, 4 and 5 (G3, G4 and G5), were fed mulberry leaves that were treated with aqueous bordeaux mixture at 5.0, 10.0 and $20.0 \%$, respectively. The bordeaux mixture solution was prepared by dissolving $1 \mathrm{~kg}$ of slaked lime and $1 \mathrm{~kg}$ of copper sulfate separately in 10 liters of water.

The evaluation of fungal contamination was performed during two seasons: spring and autumn. At the end of each creation instar were collected six caterpillars and six mulberry leaves of each group bed (two on each repetition). During the assessment, the surfaces of the mulberry leaves and the Bombyx mori integument were exposed, by contact, to the culture medium. Prior to sampling, the Petri dishes were identified, sealed and incubated at $25^{\circ} \mathrm{C}$ for 48 hours. After incubation, growth was verified 
by enumerating the colony-forming units per plate (CFU/plate) (MARGATHO et al., 2012).

For the evaluation of viral contamination, the viral inoculum of Bombyx mori nucleopolyhedrovirus, BmNPV, which was geographically isolated from Paraná, Brazil(GenBankAccessionn ${ }^{\circ}$ EU251694.1), was obtained from previously infected silkworms. The viral suspension was quantified by counting the number of viral polyhedron in a Neubauer chamber at a concentration of $2.4 \times 10^{7} \mathrm{POB} / \mathrm{mL}$ $(\mathrm{POB}=$ polyhedral occlusion bodies per milliliter $)$ (PEREIRA et al., 2008).

The inoculation was performed with one hundred silkworms in the fifth instar for each group 24 hours after ecdysis. In this case, $10 \mu \mathrm{L}$ of virus suspension was placed on mulberry leaf discs (diameter $2 \mathrm{~cm}^{3}$ ), provided as food. During feeding, the silkworms remained individually confined using disposable cups to ensure the intake of the whole virus suspension. Thereafter, the larvae were fed four times a day free-viral-inoculum leaves, as in the above treatments.

Upon microscopic preparation, samples from two silkworms from each group, from the 2nd to 9th days post-inoculation (dpi) at intervals of 24 hours, were randomly selected, anesthetized in the cold and ethyl ether for 10 minutes and dissected.
Body segments were individually packaged in vials containing $7 \%$ formaldehyde for 24 hours at $4{ }^{\circ} \mathrm{C}$.

Furthermore, the segments continued the routine histological steps for paraffin embedding. The included material was sectioned in an Olympus CUT4055 microtome with a thickness of 7 micrometers. The obtained samples were stained using the Azan cytochemical technique modified for viral occlusion bodies (HAMM, 1966), followed by analysis with an Olympus BX60 light microscope, in which the fields of interest were photomicrographed.

The averages were compared by Tukey test at 5\% probability using SAS (1993).

\section{Results and Discussion}

In the $B$. mori creation in the fall, the highest level of fungal contamination of mulberry leaves in the bed was found in the control group, with an average of 65.33 UFC, and was statistically equal to the group whose leaves were treated with water. When using the bordeaux mixture, there was a reduction of at least $53 \%$ of the contamination in the control group, with no difference between the groups receiving bordeaux mixture (Table 1). The fungus that was identified in the contamination was Beauveria bassiana.

Table 1. Fungal contamination in mulberry leaves and in the integument of caterpillars of $B$. mori, in colony-forming units (CFU), using aqueous solutions with bordeaux mixture (BM) at three concentrations and during two seasons.

\begin{tabular}{lcccc}
\hline & \multicolumn{2}{c}{ Leaves } & \multicolumn{2}{c}{ Caterpillars } \\
\hline Groups & Autumn & Spring & Autumn & Spring \\
\hline G1 (control) & $65.33 \pm 9.50 \mathrm{a}^{1}$ & $263.70 \pm 28.97$ & $69.00 \pm 1.00 \mathrm{~b}$ & $64.44 \pm 16.54 \mathrm{ab}$ \\
G2 (water) & $59.67 \pm 9.10 \mathrm{a}$ & $276.50 \pm 47.60$ & $77.67 \pm 3.22 \mathrm{a}$ & $74.33 \pm 7.57 \mathrm{a}$ \\
G3 (BM 5\%) & $29.33 \pm 8.51 \mathrm{~b}$ & $203.00 \pm 76.59$ & $49.33 \pm 2.31 \mathrm{c}$ & $49.38 \pm 11.21 \mathrm{~b}$ \\
G4 (BM 10\%) & $30.33 \pm 8.08 \mathrm{~b}$ & $198.70 \pm 36.63$ & $17.33 \pm 4.93 \mathrm{~d}$ & $42.86 \pm 24.20 \mathrm{~b}$ \\
G5 (BM 20\%) & $28.33 \pm 2.08 \mathrm{~b}$ & $201.70 \pm 7.77$ & $17.67 \pm 3.22 \mathrm{~d}$ & $38.75 \pm 18.17 \mathrm{~b}$ \\
\hline
\end{tabular}

${ }^{1}$ Means followed by the same letters in the same column, do not differ by Tukey test $(5 \%)$. 
The CFU count in the leaves of the creation in the spring, considering the control group, was higher by $106.9 \%$ than the creation in the autumn. Typical climatic characteristics of spring contributed to the development of fungi in the leaves. During this period, there was no effective use of the bordeaux mixture in a significant reduction in CFU values; however, a reduction in fungal development was observed when bordeaux mixture was used; for example, in groups 3, 4 and 5, the amount of CFU was $23 \%$ lower compared to that of the control group. Regardless of the dose of the bordeaux mixture, the observed reduction of CFU seems to be the best possible because the CFU values that were obtained for the groups that were given bordeaux mixture differ by less than $2.2 \%$.

For the counts in the integument of silkworms in the fall, the highest value (77.67 CFU) was found in the group whose leaves were treated with water, which indicated that the humidity in the creation bed in the absence of bordeaux mixture contributed to the development of fungi. Then, considering the amount of CFU, the highest value (69.00 CFU) was obtained for the control group, followed by G3, G4 and G5, with no difference between the latter two groups (with the use of syrup with 10 and $20 \%$ bordeaux mixture). For the presence of fungi in the tegument of the caterpillars in the spring, the number of CFU was higher when the mulberry leaves were treated with water compared with the treatment with bordeaux mixture, with no significant effect for the various concentrations that were evaluated.

Alves (1998) stated that entomopathogenic fungi are favored by higher temperatures, explaining the higher incidence of these pathogens in the spring. During the first creation of the year that began in April 2013, in the fall, the unfavorable weather conditions may have contributed to lower values in the count of colony-forming units in the leaves compared to the values of the next creation. Still, for the creation in the spring, the weather conditions were more favorable to the proliferation of fungi, but even without a significant difference, the average reduction in CFU integument of caterpillars in the spring was $23.37,33.49$ and $39.86 \%$, respectively, for G3, G4 and G5 compared with the control.

A microscopic examination of larvae of B. mori that were experimentally inoculated with BmNPV and fed mulberry leaves that were treated with $20 \%$ of the bordeaux mixture (G5) revealed the presence of polyhedral occlusion bodies or viral polyhedra concentrates in the apical region of columnar cells the midgut epithelium from 7th dpi (Figure 1). The polyhedra were of varying size, but most were small and were present in the hemocele and in various organs and tissues of $B$. mori, such as the trachea, fat tissue and tegument (Figure 2). The muscle tissue and Malpighian tubules, even uninfected, were disorganized (not shown).

The infected tissues were in different stages of the infectious cycle (Figure 2B), which indicated asynchronous BmNPV replication. The cytology was consistent with Alphabaculovirus infection, and in the infected nuclei, one can observe the viroplasm or virogenic stroma and viral polyhedra. Following the infection process, there was a lysis of the nuclear envelope and the plasma membrane, which resulted in the release of polyhedra in the hemocele. Similar results were observed in G1 and G2.

The larvae that were treated with $5 \%$ bordeaux mixture (G3) had viral polyhedra only at the apex of the columnar cells of the midgut epithelium but were not present in other organs and tissues of the insect's body. The cells of the fatty tissue showed hypertrophic nuclei, and we could observe an evident increase in the number of hemocytes in the hemocoel compared with the control. Other organs and tissues revealed no changes that could be related to viral infection. However, the presence of BmNPV in the midgut, the organ that is responsible for nutrient absorption, compromises insect metabolism and therefore survival. Figure 3 shows the control midgut epithelium for comparison. 
Figure 1. Photomicrographs of the intestinal wall of caterpillars of B. mori that were inoculated with BmNPV, 8th dpi, and supplemented with $20 \%$ bordeaux mixture (G5); Azan staining modified. In the medium intestinal epithelium (Ep), containing large amount of viral polyhedra (in red and black arrows) at the apex of the columnar cells; better visibility is in $\mathrm{B}$, where you can see the difference in the size of the viral polyhedra. Hemocele (He), containing free polyhedra (arrow leaked), muscle tissue (M) and intestinal lumen (Lu).
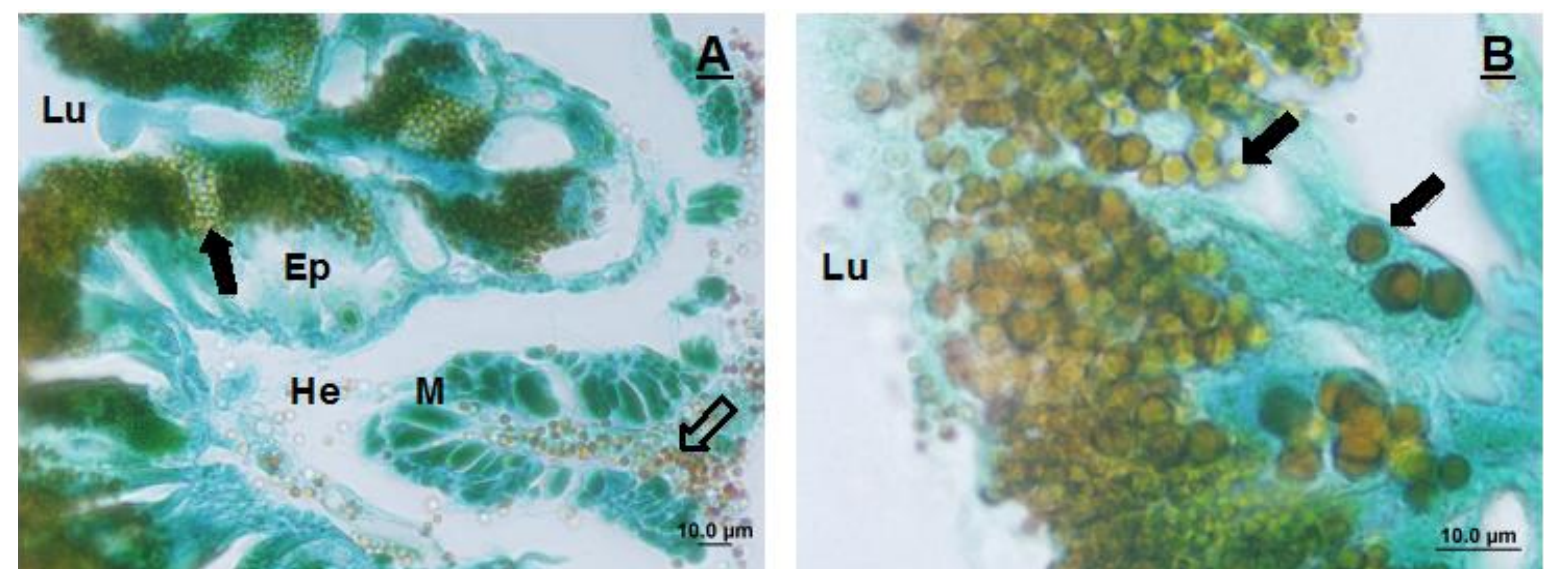

Figure 2. Photomicrographs of tissues of caterpillars of B. mori that were inoculated with BmNPV, 8th dpi, and treated with $20 \%$ bordeaux mixture, G5 group; Azan staining modified. In the integument (Tg) and fatty tissue (G) containing large amounts of viral polyhedra (in red) in the nucleus of its cells. Free polyhedra (in red and black arrows) in the hemocele $(\mathrm{He})$, better visibility is in B, where you can see in infected nuclei of epithelial cells in the integument the different stages of the infectious cycle. Viroplasma (white arrow), polyhedra in cell cytoplasm, after lysing the nuclear wrap (arrow leaked).

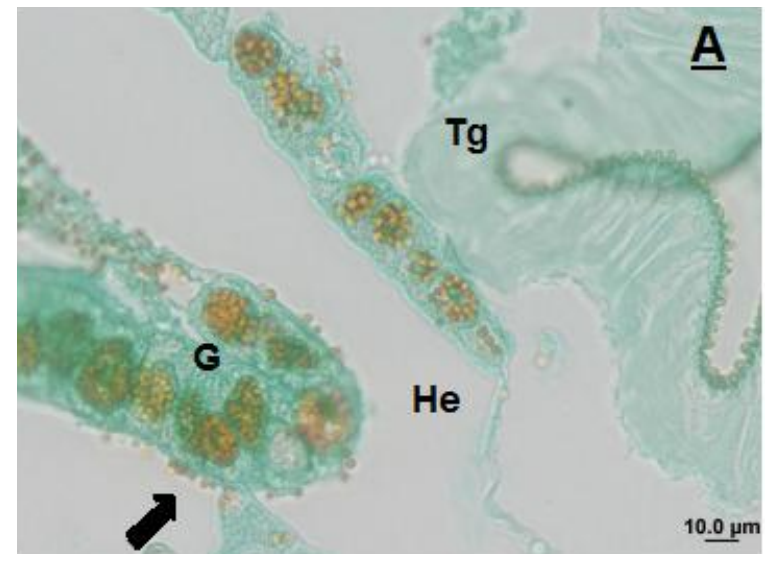

Because the larvae that were treated with $10 \%$ bordeaux mixture (G4) did not show a viral polyhedron at the analyzed times, as in G3, there

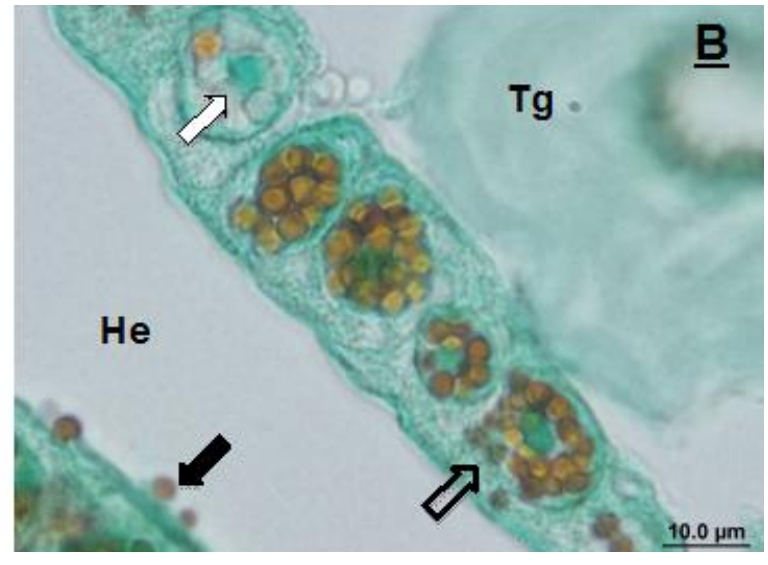

was an increase in the number of hemocytes in the hemocoel, many of which were surrounding the trachea and fat tissue (Figure 4). 
Figure 3. Photomicrography of control midgut of caterpillars of B. mori. Columnar cells (Cc), microvilli (black arrow), muscle tissue (white arrow), caliciform cells (Ca), intestinal lumen ( $\mathrm{Lu}$ ) and haemocel (He); Mallory staining."

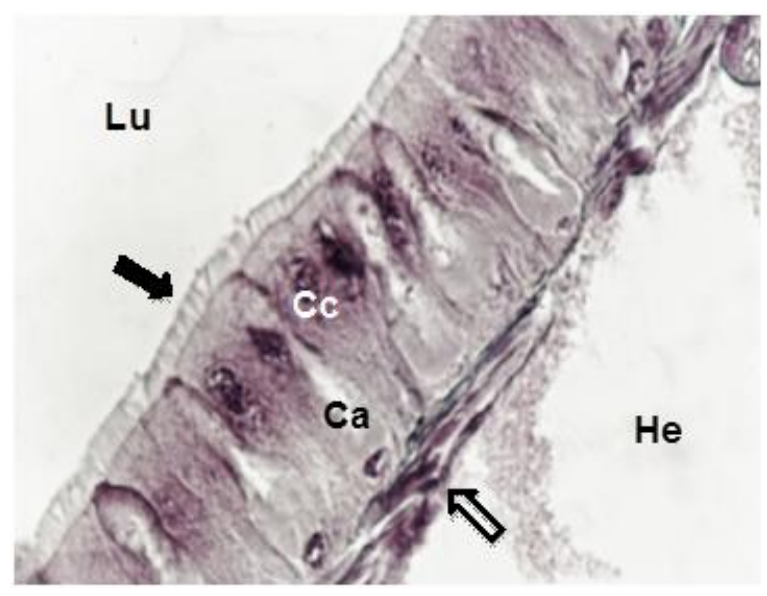

Figure 4. Photomicrography of trachea (Tr) and hemocytes (black arrow) of caterpillars of B. mori inoculated with BmNPV, 8th dpi, and treated with 10\% bordeaux mixture (G4); Azan staining modified. See the concentration of hemocytes around the trachea. Hemocele $(\mathrm{He})$.

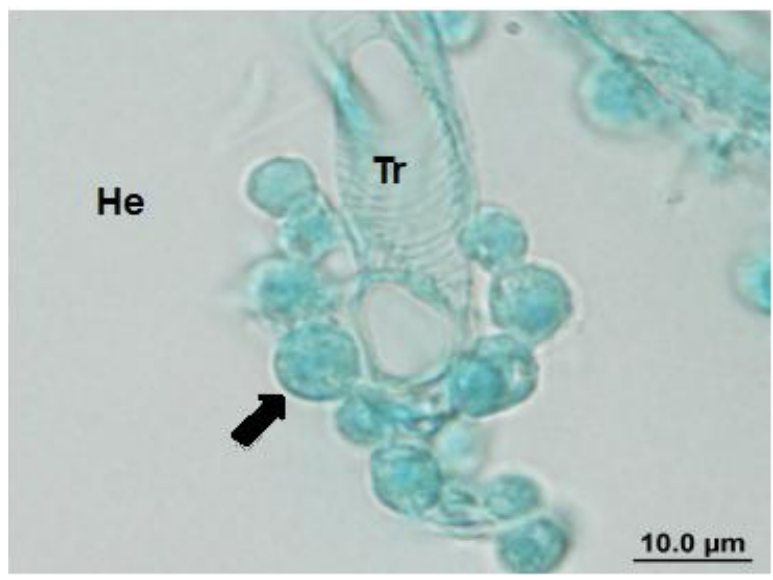

Regarding virus infection, Strand and Pech (1995) stated that in general, the host eliminates endoparasites by encapsulation mechanisms, in which hemocytes form a series of envelopes covering the invasive structure, as confirmed by Lavine and Strand (2002). Chouvenc et al. (2009) demonstrated that these insect defense cells use the phagocytosis mechanism for the recognition and removal of different pathogens. The increase in the number of hemocytes in the inoculated groups demonstrated the presence of this basic mechanism of defense of B. mori against BmNPV.
It is noteworthy that when using $10 \%$ bordeaux mixture, hemocytes were found near the tracheal system. The trachea is responsible for aeration, and a series of studies have demonstrated its role in the spread of infection by baculovirus, including the BmNPV in the insect body (BRANCALHÃO et al., 2009; KIRKPATRICK et al., 1994; PEREIRA et al., 2008; RAHMAN; GOPINATHAN, 2004; TORQUATO et al., 2006). The epidermal cells of the tracheal epithelium are organized morphologically and form a type of common lymphatic system, which acts as a virus-crossing canal, thus permitting 
the rapid attainment of the pathogen to organic systems. In addition, branches of the tracheal system penetrating insect tissues go through the basal lamina, a structure that acts as a selective filter for the passage of macromolecules and particles, such as viruses (PASSARELLI, 2011). Thus, the presence of hemocytes near the trachea strengthens their immune action on this organic system, which is considered an important disperser of viral infection and is responsible for the positive effects of this concentration of bordeaux mixture in controlling infection BmNPV.

Furthermore, two types of hemocyte encapsulation mechanisms are described: cells that occur without melanization and melatonin cells in which melanin prevents or delays the growth of the pathogen. Melanin is formed primarily during the oxidation and polymerization of phenols, such as tyrosine and dopamine, by enzymes that are collectively referred to as phenoloxidases (NAPPI et al., 1991, 1992; BECKAGE, 1998). The effects of melanization due to the activity of phenoloxidases have been described for the past 60 years. The phenol oxidase enzyme or tyrosinase contains copper, which justifies the greatest protective effect that is conferred by the addition of bordeaux mixture to the diet of insects.

Polyhedra are viral resistance structures that persist for a long time in the environment (ADAMS; MCCLINTOCK, 1991), and because transmission occurs orally (BERRETTA et al., 2013), the infection starts when the virions are released from the polyhedron (occlusion-derived bodies - ODB) in the lumen of the midgut by the action of alkaline $\mathrm{pH}$ and proteins of the digestive juice, such as serine protease and fluorescent red. The ODB merge with epithelial cells, thus releasing the nucleocapsid into the cytoplasm, and can start their infectious cycle, producing bud virus (budded virus - BV), which is responsible for secondary or systemic infection from cell to cell in the insect's body (ROHRMANN, 2011; SATADAL et al., 2012).
In the environment, a BmNPV polyhedron can adhere to mulberry leaves, and leaves that are treated with bordeaux mixture have a slightly alkaline pH. Tuan et al. (1989) reported that the virus of the nuclear polyhedrosis of Heliothis armigera, HSNPV, was inactivated by alkaline dew (pH 8.1) that was collected from soybean leaves. Gudauskas and Canerday (1968), Andrews and Sikorowski (1973) and Young et al. (1977) showed that the leaf $\mathrm{pH}$ is a factor in the inactivation of NPV.

Based on these observations, the alkaline $\mathrm{pH}$ resulting from treatment with bordeaux mixture should affect the integrity of the BmNPV polyhedral structure, which is essential for the persistence of the virus in the environment, because it protects the ODB that are required for primary infection.

Furthermore, studies by Blissard and Wenz (1992) showed that during the infectious process, BV enters the host cells by endocytosis mediated by the viral envelope glycoprotein GP64, whose operation is $\mathrm{pH}$ dependent, in which a $\mathrm{pH}$ of 5.5 or less is necessary. Because BV are responsible for systemic infection, the $\mathrm{pH}$ variation again should influence the virus spread in the body of $B$. mori, thereby affecting the operation of GP64 and interfering with the endocytic mechanisms of BV. These data can account for the effects of bordeaux mixture, where, even at non-optimal concentrations $(5 \%)$, the infection was restricted in the midgut epithelium, caused by ODB, with no dispersal to other tissues that are known to be susceptible to BmNPV.

This study represents the first report of action of bordeaux mixture on $B$. mori pathogens.

\section{Conclusion}

The bordeaux mixture solution at a concentration of $10 \%$ is indicated for the prevention of fungal diseases.

In terms of viral diseases, concentrations of 5\% and $20 \%$ bordeaux mixture do not exert a protective 
effect; however, the concentration of $10 \%$ acts positively for activating the insect's defense mechanisms that leads to increased resistance to BmNPV.

\section{Acknowledgments}

To FAPESP (process $n^{\circ} 12 / 24430-1$ ), Araucaria Foundation and Bratac silk industry for financial support.

\section{Ethics and Biosecurity}

Protocol no 01/2009 from the Ethics Committee on Animal Experimentation (CEEA) of Universidade Estadual Paulista (UNESP), Campus of Dracena.

\section{References}

ADAMS, J. R.; MCCLINTOCK, J. T. Baculoviridae. nuclear polyhedrosis viruses. Nuclear polyhedrosis viruses of insects. In: ADAMS, J. R.; BONAMI, J. R. Atlas of invertebrate viruses. Boca Raton: CRC, 1991. Part 1, p. 87-204.

ALVES, S. B. (Ed.). Patologia e controle microbiano. Controle microbiano de insetos. Piracicaba: FEALQ, 1998. p. 21-37.

AMARAL, E.; ALVES, S. B. Insetos úteis. Piracicaba: Livroceres, 1979. $188 \mathrm{p}$.

ANDREWS, G. L.; SIKOROWOSKI, P. P. Effects of cotton leaf surface on the nuclear polyhedrosis virus of Heliothis zea and Heliothis virescens (Lepidoptera: Noctuidae). Journal of Invertebrate Pathology, New York, v. 22, n. 2, p. 290-291, 1973.

BECKAGE, N. E. Parasitoids and polydnaviruses. Bioscience, Uberlândia, v. 48, n. 4, p. 305-311, 1998.

BERRETTA, M. F.; FERRELLI, M. L.; SALVADOR, R.; SCIOCCO, A.; ROMANOWSKI, V. Baculovirus Gene Expression. In: ROMANOWSKI, V. Current issues in molecular virology: viral genetics and biotechnological applications. Rijeka: Intech, 2013. p. 57-78.

BLISSARD, G. W.; WENZ, J. R. Baculovirus GP64 envelope glycoprotein is sufficient to mediate $\mathrm{pH}$ dependent membrane fusion. Journal of Virology, Washington, v. 66, n. 11, p. 6829-6835, 1992.
BRANCALHÃO, R. M. C. Vírus entomopatogênicos no bicho-da-seda: taxonomia e citopatologia causada por Nucleopolyhedrovirus em células de Bombyx mori. Biotecnologia Ciência \& Desenvolvimento, Brasília, n. 24, p. 54-58, 2002.

BRANCALHÃO, R. M. C.; RIBEIRO, L. F. C. Citopatologia da infecção causada por BmNPV no tegumento de Bombyx mori L., 1758 (Lepidoptera: Bombycidae). Arquivos de Ciências Veterinárias e Zoologia da Unipar, Umuarama, v. 6, n. 1, p. 15-20, 2003.

BRANCALHÃO, R. M. C.; TORQUATO, E. F. B.; FERNANDEZ, M. A. Cytopathology of Bombyx mori (Lepidoptera: Bombycidae) silk gland caused by multiple nucleopolyhedrovirus. Genetics and Molecular Research, Ribeirão Preto, v. 8, n. 1, p. 162-179, 2009.

CHOUVENC, T.; SU, N. Y.; ROBERT, A. Cellular encapsulation in the eastern subterranean termite, Reticulitermes flavipes (Isoptera), against infection by the entomopathogenic fungus Metarhizium anisopliae. Journal of Invertebrate Pathology, New York, v. 101, n. 3, p. 234-241, 2009.

CORRADELO, E. F. A. Bicho-da-seda e amoreira: da folha ao fio a trama de um segredo milenar. São Paulo: Ícone, 1987. $101 \mathrm{p}$.

DINIZ, L. P.; MAFFIA, L. A.; DHINGRA, O. D.; CASALI, V. W. D.; SANTOS, R. H. S.; MIZUBUTI, E. S. G. Avaliação de produtos alternativos para controle da requeima do tomateiro. Fitopatologia Brasileira, Brasília, v. 31, n. 2, 171-179, 2006.

FONSECA, T. C.; FONSECA, A. S. Cultura da amoreira e criação do bicho-da-seda. São Paulo: Nobel, 1988. 246 p.

GALLO, D.; NAKANO, O.; SILVEIRA NETO, L.; CARVALHO, R. P. L.; BATISTA, G. C.; BERTI FILHO, E.; PARRA, J. R. P.; ZUCCHI, R. A.; ALVES, S. B.; VENDRAMIM, J. D.; MARCHINI, L. C.; LOPES, J. R. S.; OMOTO, C. Entomologia agrícola. Piracicaba: FEALQ, 2002. $920 \mathrm{p}$.

GUDAUSKAS, R. T.; CANERDAY, D. The effect of heat, buffer salt and $\mathrm{H}$-ion concentration and ultraviolet light on the infectivity of Heliothis and Trichoplusia nuclear polyhedrosis viruses. Journal of Invertebrate Pathology, New York, v. 12, n. 3, p. 405-411, 1968.

HAMM, J. J. A modified azan staining technique for inclusion body viruses. Journal of Invertebrate Pathology, New York, v. 8, n. 1, p. 125-126, 1966. 
KANAFI, R. R.; EBADI, R.; MIRHOSSEINI, S. Z.; SEIDAVI, A. R.; ZOLFAGHARI, M.; ETEBARI, K. A review on nutritive effect of mulberry leaves enrichment with vitamins on economic traits and biological parameters of silkworm Bombyx mori L. Invertebrate Survival Journal, Modena, v. 4, n. 2, p. 86-91, 2007.

KIRKPATRICK, B. A.; WASHBURN, E. K.; ENGELHARD, E. K.; VOLKMAN, L. E. Primary infection of insect traqueae by Autographa californica M nuclear polyhedrosis virus. Journal of Virology, Washington, v. 203, n. 1, p. 184-186, 1994.

LAVINE, M. D.; STRAND, M. R. Insect hemocytes and their role in immunity. Insect Biochemistry and Molecular Biology, Oxford, v. 32, n. 10, p. 1295-1309, 2002.

MARGATHO, L. F. F.; OKAMOTO, F.; ALMEIDA, A. M.; SANTOS, C. A. J. P. Avaliação quantitativa da contaminação por microorganismos no ambiente de criação do bicho-da-seda (Bombyx mori L.) na fase de chocadeira. Arquivos do Instituto Biológico, São Paulo, v. 79 , n. 2, p. 233-238, 2012

MARTINS, F.; PEREIRA, J. A.; BAPTISTA, P. Oxidative stress response of Beauveria bassiana to Bordeaux mixture and its influence on fungus growth and development. Pest Management Science, Oxford, v. 70, n. 8, p. 1220-1227, 2014.

NAPPI, A. J.; CARTON, Y.; FREY, F. Parasite-induced enhancement of hemolymph tyrosinase activity in a selected immune reactive strain of Drosophila melanogaster. Archives of Insect Biochemistry and Physiology, Malden, v. 18, n. 3, p. 159-168, 1991.

NAPPI, A. J.; CARTON, Y.; LI, J.;VASS, E. Reduced cellular immune competence of a temperature sensitive dopa decarboxylase mutant strain of Drosophila melanogaster against the parasite Leptopilina boulardi. Comparative Biochemistry and Physiology, Oxford, v. 101, n. 3, p. 453-460, 1992.

NICODEMO, D.; OLIVEIRA, J. E.; SEDANO, A. A.; MARCONCINI, J. N.; TONOLI, G. H. D. Impact of different silkworm dietary supplements on its silk performance. Journal of Materials Science, Berlin, v. 49, n. 18, p. 6302-6310, 2014.

OKINO, I. Manual de sericicultura. Bauru: CATI/SAA, 1982. $80 \mathrm{p}$.

PARRA, J. R. P. Técnicas de criação de insetos para programas de controle biológico. 6. ed. Piracicaba: ESALQ/FEALQ, 2001. 134 p.

PASSARELLI, A. L. Barriers to success: how baculovirus establish efficient systemic infections. Journal of Virology, Washington, v. 411, n. 2, p. 383-392, 2011.
PAULUS, G.; MULLER, A. M.; BARCELlOS, L. A. R. Agroecologia aplicada: práticas e métodos para uma agricultura de base ecológica. Porto Alegre: EMATER/ RS, 2000. 86 p.

PEREIRA, E. P.; CONTE, H.; RIBEIRO, L. F.; ZANATTA, D. B.; BRAVO, J. P.; FERNANDEZ, M. A.; BRANCALHÃO, R. M. Cytopathological process by multiple nucleopolyhedrovirus in the testis of Bombyx mori L., 1758 (Lepidoptera: Bombycidae). Journal of Invertebrate Pathology, New York, v. 99, n. 1, p. 1-7, 2008.

PERUCH, L. A. M.; BRUNA, E. D. Relação entre doses de calda bordalesa e de fosfito potássico na intensidade do míldio e na produtividade da videira cv. 'Goethe'. Ciência Rural, Santa Maria, v. 38, n. 9, p. 2413-2418, 2008.

POLYCARPO, G. V.; SILVA, A. A. R.; FRUCHI, V. M.; RIGOBELO, E. C.; CRUZ, V. C.; NICODEMO, D. Enriquecimento da dieta do bicho-da-seda com extrato hidrossolúvel de soja. Ciência Rural, Santa Maria, v. 42, n. 9, p. 1669-1674, 2012.

PORTO, A. J.; OKAMOTO, F.; IKUNO, A. A.; FERREIRA, V. C. A.; MARGATHO, L. F. F. Avaliação biológica e produtiva do bicho-da-seda (Bombyx mori L.) alimentado com folhas de amoreira pulverizadas com extrato de Mirabilis jalapa. Arquivos do Instituto Biológico, São Paulo, v. 72, n. 4, p.445-453, 2005.

RAHMAN, M. M.; GOPINATHAN, K. P. Systemic and in vitro infection process of Bombyx mori nucleopolyhedrovirus. Virus Research, Amsterdam, v. 101, n. 2, p. 109-118, 2004.

ROHRMANN, G. F. Baculovirus molecular biology. 2. ed. Bethesda, MD: National Library of Medicine, US, National Center for Biotechnology Information, 2011. Available at: <http://www.ncbi.nlm.nih.gov/books/ NBK49500/>. Accessed at: 22 set. 2014.

SAS INSTITUTE - Statistical analysis systems. User's guide: stat. Version 6. 4. ed. Cary, NC, 1993. 890p.

SATADAL, C.; SUMAN, D.; SAHA, A. K.; HAZRA, N. Dimorphisim in nuclear polyhedrosis virus (BmNPV) (Family: baculoviridae) causing 'grasserie' disease in silkworm (Bombyx mori L.): light and electron microscopy and protein profile. Applied Biological Research, New Delhi, v. 14, n. 2, p. 176-186, 2012.

SOUTO, R. A.; MALAGODI, E.; MARACAJÁ, M. C. S.; XAVIER, C. Análise da viabilidade ambiental de práticas agroecológicas adotadas por agricultores familiares do município de Lagoa Seca, Paraíba. Engenharia Ambiental, Espírito Santo do Pinhal, v. 8, n. 3, p. 99-115, 2011. 
STRAND, M. R.; PECH, L. L. Immunological basis for compatibility in parasitoid host relationships. Annual Review of Entomology, Palo Alto, v. 40, p. 31-56, 1995.

SURENDRA, N. B.; SURENDRA, K. R. P. Toxic impact of organophosphorus inseticides on acetylcholinesterase activity in the silkworm, Bombyx mori L. Ecotoxicology Enviromental Safety, New York, v. 42, n. 2, p. 157-162, 1999.

TINOCO, S. T. J.; PORTO, A. J.; ALMEIDA, A. M.; SOUZA, C. G.; OKAMOTO, F.; OKAWA, H.; ALMEIDA, J. E.; TAKAHASHI, J. N.; MARGATHO, L. F. F.; NAKATA, N.; FONSECA, T. C.; UCHINO, T.; HIGASHIKAWA, T.; SILVA, W. H. Manual de sericicultura. Campinas: CATI/SAA, 2000. 71 p.
TORQUATO, E. F. B.; MIRANDA NETO, M. H.; BRANCALHÃO, R. M. C. Nucleopolyhedrovirus infected central nervous system cells of Bombyx mori (L.) (Lepidoptera: Bombycidae). Neotropical Entomology, Londrina, v. 35, n. 1, p. 70-74, 2006.

TUAN, S. J.; TANG, L. C.; HOU, R. F. Factors affecting pathogenicity of NPV preparations to the corn earworm, Heliothis armigera. Entomophaga, Berlin, v. 34, n. 4, p. 541-559, 1989. Available at: <http://www.springerlink. com/content/h415802040g6h337/>. Accessed at: 11 set. 2014.

YOUNG, S. Y.; YEARIAN, W. C.; KIM, K. S. Effect of dew from cotton and soybean foliage on activity of Heliothis NPV. Journal of Invertebrate Pathology, New York, v. 29, n. 1, p. 105-111, 1977. 
